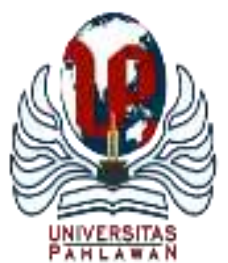

Edukatif : Jurnal Ilmu Pendidikan Volume 3 Nomor 5 Tahun 2021 Halm 3189 - 3195 EDUKATIF: JURNAL ILMU PENDIDIKAN

Research \& Learning in Education

https://edukatif.org/index.php/edukatif/index

\title{
Pengembangan Bahan Ajar Tema 7 Indahnya Keberagaman Negeriku Subtema 2 Berbasis Lokal di Sekolah Dasar
}

\author{
Badratun Nafis $^{1 凶}$, Maylana Nurfariha ${ }^{2}$, Srimau Aisyah $^{3}$, Tria Marvida \\ Universitas Islam Negeri Sunan Kalijaga, Indonesia ${ }^{1,2,3,4}$ \\ E-mail :20204082013@ student.uin-suka.ac.id ${ }^{1}, 20204082002 @$ student.uin-suka.ac.id $^{2}$, \\ 20204082001@ @ student.uin-suka.ac.id ${ }^{3}, 20204082012 @$ student.uin-suka.ac.id $^{4}$
}

\begin{abstract}
Abstrak
Penelitian ini dilatarbelakangi oleh perlunya memperhatikan sejauh mana pemikiran siswa berkembang di kelas dan menyempurnakan konsep dengan mengembangkan bahan ajar berbasis kearifan budaya lokal. Penelitian ini berfokus pada analisis kemungkinan dan kebutuhan pembelajaran yang mendasari pengembangan materi Sub Tema 2 pada Tema 7. Subjek penelitian adalah kurikulum 2013 kelas 4 SDN 1 Peukan Bada Aceh Tahun ajaran 2020/2021. Objek penelitiannya meliputi profil standar kompetensi, dan kompetensi dasar SDN 1 Peukan Bada Aceh yang diajarkan dengan berbasis budaya lokal. Data penelitian dikumpulkan melalui wawancara online. Instrumen yang digunakan dalam penelitian ini adalah pedoman wawancara. Metodologi yang digunakan dalam penelitian ini yaitu R\&D, yang memiliki tiga tahap: pendefinisian, perancangan, dan pengembangan. Tahap pendefinisian meliputi analisis kurikulum, siswa, sumber daya, materi dan perumusan hasil. Tahap kedua dirancang untuk merancang materi yang sesuai dengan hasil belajar dan indikator yang telah ditetapkan. Tahap ketiga, tahap pengembangan, bertujuan untuk menghasilkan bahan ajar yang efektif dengan menguji keefektifan bahan ajar. Hasil dari penelitian ini yaitu keseluruhan KD yang termuat dalam tema 7 subtema 1 bisa diintegrasikan ke dalam pembelajaran berbasis lokal materi. Konsep lokal materi yang dapat diintegrasikan ke dalam pembelajaran tema 7 subtema 2 adalah konsep materi gerak tari daerah. Materi pembelajaran berbasis budaya lokal dapat digunakan sebagai alat untuk menanamkan kearifan lokal (local wisdom) kepada siswa. Analisis Rencana Pelaksanaan Pembelajaran (RPP) yang dibuat oleh guru-guru di SDN 1 Peukan Bada menujukkan bahwa guru berusaha untuk membuat perencanaan pembelajaran yang berpusat pada siswa dengan menerapkan pembelajaran yang sesuai dengan karakteristik materi ajarnya.
\end{abstract}

Kata Kunci: pengembangan, bahan ajar tematik, lokal materi.

\begin{abstract}
This research is motivated by the need to pay attention to the extent to which students' thinking develops in class and refine the concept by developing teaching materials based on local cultural wisdom. This study focuses on the analysis of learning possibilities and needs that underlie the development of Sub-Theme 2 material in Theme 7. The subject of the research is the 2013 curriculum for grade 4 SDN 1 Peukan Bada Aceh for the 2020/2021 academic year. The object of the research includes profiles of competency standards, and basic competencies of SDN 1 Peukan Bada Aceh which are taught based on local culture. Research data were collected through online interviews. The instrument used in this study was an interview guide. The methodology used in this research is $R \& D$, which has three stages: definition, design, and development. The defining stage includes the analysis of curriculum, students, resources, materials and formulation of results. The second stage is designed to design materials in accordance with the learning outcomes and indicators that have been set. The third stage, the development stage, aims to produce effective teaching materials by testing the effectiveness of teaching materials. The result of this research is that all of the basic competencies contained in theme 7 sub-theme 1 can be integrated into local-based learning materials. The local concept of material that can be integrated into the learning of theme 7 sub-theme 2 is the concept of regional dance movement material. Local culture-based learning materials can be used as a tool to instill local wisdom in students. The analysis of the Learning Implementation Plan (RPP) made by the teachers at SDN 1 Peukan Bada shows that teachers are trying to make student-centered learning plans by implementing learning according to the characteristics of the teaching material.
\end{abstract}

Keywords: development, thematic teaching materials, local materials.

Copyright (c) 2021 Badratun Nafis, Maylana Nurfariha, Srimau Aisyah, Tria Marvida

$\triangle$ Corresponding author

Email : 20204082013@student.uin-suka.ac.id

DOI : https://doi.org/10.31004/edukatif.v3i5.1121

ISSN 2656-8063 (Media Cetak)

ISSN 2656-8071 (Media Online)

Edukatif : Jurnal Ilmu Pendidikan Vol 3 No 5 Tahun 2021 p-ISSN 2656-8063 e-ISSN 2656-8071 
3190 Pengembangan Bahan Ajar Tema 7 Indahnya Keberagaman Negeriku Subtema 2 Berbasis Lokal di Sekolah Dasar - Badratun Nafis, Maylana Nurfariha, Srimau Aisyah, Tria Marvida

DOI: https://doi.org/10.31004/edukatif.v3i5.1121

\section{PENDAHULUAN}

Bahan ajar adalah bahan atau materi pelajaran yang disusun secara sistematis, yang digunakan guru dan siswa dalam proses pembelajaran. Bahan ajar memiliki peranan penting dalam mencapai tujuan pembelajaran (Latifah 2018, 2). Pengembangan bahan ajar pada tematik bisa memfasilitasi guru dalam menerapkan proses pembelajaran sesuai dengan lingkungan serta karakteristik siswa. Berdasarkan hasil penelitian, pembelajaran itu bisa dikatakan baik apabila ketika melakukan proses pembelajaran menempatkan guru sesuai dengan lingkungan serta karakteristik siswa-siswi, selain itu juga memposisikan guru sebagai fasilitator, motivator, serta pembimbing siswa dalam mengkonstruksi pengetahuan yang dimiliki.

Pembelajaran adalah upaya memfasilitasi yang diterapkan guru guna memudahkan siswa-siswi belajar mandiri. Sekarang ini proses pembelajaran di dalam kelas menggunakan pendekatan tematik terpadu karena itu pengembangan bahan ajar hendaknya berbasis tematik terpadu. Untuk menyiapkan bahan ajar tematik yang baik, sehingga kita memerlukan pemahaman yang baik mengenai pembelajaran tematik terpadu, dengan begitu kita menjadi tidak merasa kesulitan mengembangkan bahan ajar tematik. (Akbar dan Sriwijaya 2011)

Pembelajaran tematik integratif adalah salah satu model pendekatan keterpaduan antara mata pelajaran satu dengan mata pelajaran lainnya, pengembangan bahan ajar tematik berbasis mata pelajaran lainnya. Materi pelajaran yang bisa dipadukan dalam suatu tema perlu memperhatikan lingkungan dan karakteristik siswasiswi. Materi yang tidak dapat dipadukan jangan dipaksakan, yang berarti materi yang mustahil bisa dipadukan jangan dipadukan. (Trianto, 2012) menyatakan bahwa model pembelajaran tematik yakni model pembelajaran terpadu yang menggunakan tema untuk menghubungkan mata pelajaran lainnya.

Pada hakekatnya pembelajaran tematik adalah pendekatan pembelajaran yang mana memperhatikan serta menyesuaikan konsep berdasarkan tingkat perkembangan berfikir siswa-siswi di dalam kelas. Berdasarkan hasil penelitian (Rusman 2010) jika dibandingkan dengan pembelajaran konvensional, pembelajaran tematik mempunyai keunggulan-keungulan, diantaranya adalah: (1) pengalaman serta kegiatan belajar sesuai dengan tingkat perkembangan dan juga kebutuhan anak SD; (2) beberapa kegiatan yang dipilih dalam implementasi pembelajaran tematik berlawanan dengan minat dan juga apa yang dibutuhkan siswasiswi; (3) kegiatan belajar lebih mempunyai makna juga kesan bagi siswa-siswi, sehingga hasil belajar siswa dapat tahan lama; (4) membantu mengembangkan keterampilan siswa-siswi dalam berpikir. Pengembagan bahan ajar tematik yang mana berbasis budaya lokal ini berdasarkan pada penelitian (Nana Syaodih Sukmadinata 2010) yang mana hasil penelitiannya yaitu: (1) Berfokus pada topik yang dibangun atas pengalaman budaya pertama siswa akan meningkatkan pemahaman mereka tentang budaya lokal. (2) meningkatnya hasil belajar ketika budaya lokal menyatu dengan pembelajaran. Berdasarkan hasil penelitian (Warpala, Subagia, dan Suastra 2010) menunjukkan bahwa bahan ajar berbasis pengetahuan budaya lokal berkontribusi baik terhadap peningkatan pemahaman konseptual serta kinerja akademik belajar siswa-siswi.

Pelaksanaan pembelajaran tematik di sekolah dasar masih menemui hambatan. Buku teks yang diterbitkan oleh Kementrian Pendidikan Kebudayaan (Kemendikbud) tahun 2014 digunakan dalam pembelajaran, tetapi isinya kurang mengintegrasikan lingkungan nyata sekitar siswa. Hal ini tidak sesuai dengan pendapat yang dikemukakan oleh Akbar bahan ajar termatik harus mampu mengakomodasikan dan menggunakan situasi riil yang terjadi di lingkungan siswa sehingga dapat menjadikan praktik pembelajaran yang bermakna bagi kehidupan siswa (Wijiningsih, Wahjoedi, dan Sumarmi 2017, 1031).

Hasil observasi dan wawancara yang peneliti lakukan menujukkan bahwa dalam pembelajaran guru masih terfokus menggunakan buku teks yang dikeluarkan oleh Kemendikbud. Padahal beberapa materi yang terdapat dalam buku tersebut tidak dapat diintegrasikan lingkungan sekitar siswa sehingga membuat siswa susah untuk memahami materi pembelajaran. Pembelajaran tersebut belum bermakna bagi siswa karena siswa tidak mampu mempelajari contoh nyata yang ada di lingkungan sekitar. Karena hal itulah guru membutuhkan bahan ajar yang memuat contoh-contoh nyata yang di lingkungan terdekat siswa. 
Adapun upaya yang dapat dilakukan dalam menyelesaikan masalah ini adalah dengan melakukan penyediaan dan penggunaan bahan ajar pendukung berbasis lokal materi yang dekat dengan kehidupan seharihari siswa. Bahan ajar ini akan membantu siswa dalam memahami materi pelajaran yang akan dipelajarinya, karena bahan ajar ini akan memberikan contoh nyata yang ada di limgkungan terdekat siswa. Dengan adanya bahan ajar berbasis lokal materi ini diharapkan dapat membuat pengalaman belajar siswa menjadi lebih bermakna.

Berdasarkan survei yang telah di lakukan I Wawan Suja berjudul "Analisis Kebutuhan Pengembangan Buku Ajar Sains SD Bermuatan Pedagogi Budaya Bali”. Temuan penelitian menunjukkan bahwa : (1) seluruh standar kompetensi Sains SD dan 99, 16\% kompetensi dasarnya strategis diajarkan dengan siklus standar Catur Pratama; (2) konsep-konsep Sains asli yang relevan diintegrasikan ke dalam kurikulum Sains SD; dan (3) daya dukung SDM dan fasilitas pembelajaran masih perlu ditingkatkan untuk penerapan pembelajaran Sains bermuatan konsep sains asli dan konteks pedagogi Catur Pratama (Suja 2011, 84).

Penelitian yang berjudul "Pengembangan Media Konkret pada Pembelajaran Tema Lingkungan Kelas III Sekolah Dasar" yang telah diterbitkan pada tahun 2018 menyimpulkan bahwa pengembangan bahar ajar yang memanfaatkan Penggunaan kincir angin dalam pembelajaran mempunyai nilai ketertarikan. Sehingga siswa menjadi aktif dan termotivasi untuk mengeksplorasi potensi yang dimiliki dengan belajar terlibat dalam pengalaman langsung (Destrinelli, Hayati, dan Sawinty 2018, 331). Oleh karena itu, berdasarkan penjelasan di atas bisa diambil kesimpulan bahwasannya bahan ajar khusus bentuk kincir angin dalam pembelajaran yang dikembangkan efektif berdasarkan hasil penilaian dan hasil wawancara dengan siswa.

Stefanus Divan dalam penelitian "Pengembangan Bahan Ajar Tematik Berbasis Budaya Lokal untuk Siswa Kelas IV Sekolah Dasar" pada tahun 2018. Berdasarkan hasil penelitian dan pengembangan dapat disimpulkan, bahan ajar tematik mampu memecahkan permasalahan bahan ajar yang digunakan oleh guru (Divan 2018, 112).

Bertitik tolak pada penelitian sebelumnya, maka penelitian ini mengangkat topik "Pengembangan Bahan Ajar Tema 7 Indahnya Keberagaman Negeriku Subtema 2 Berbasis Lokal Materi Kelas IV SDN 1 Peukan Bada".

\section{METODE PENELITIAN}

Penelitian ini fokus pada analisis potensi dan kebutuhan pembelajaran yang mendasari pengembangan bahan ajar tema 7 subtema 2. Subjek penelitian adalah kurikulum 2013 kelas 4 SDN 1 Peukan Bada Aceh Tahun ajaran 2020/2021. Objek penelitian meliputi gambaran standar kompetensi dan kemampuan dasar SDN 1 Peukan Bada Aceh yang diajarkan dengan berbasis budaya lokal. Data penelitian dikumpulkan melalui wawancara online. Dalam penelitian ini, instrumen yang digunakan yakni pedoman wawancara. Wawancara kepada guru dilakukan untuk mendapatkan informasi daya dukung dan pemahaman sekolah terhadap pembelajaran kesenian (Suja, t.t., 85). Penelitian ini menggunakan jenis penelitian Research and Development $(\mathrm{R} \& \mathrm{D})$.

Metode yang digunakan dalam penelitian ini terdiri atas 3 tahapan, yaitu: Tahapan pertama, pendefinisian yang meliputi pertama analisis kurikulum. Analisis kurikulum dimaksudkan sebagai dasar untuk pengembangan indikator dan hasil belajar, serta konsep yang dikembangkan dalam literatur. Analisis siswa yang kedua adalah kajian karakteristik siswa dengan menggunakan materi yang terdiri atas analisis usia, motivasi belajar, kemampuan belajar, psikomotorik dan keterampilan sosial. Ketiga, analisis bahan ajar yang bertujuan mengidentifikasi isi dan bahan ajar sekolah sebagai konsep yang dibangun ke dalam bahan ajar. Materi sekolah ditentukan berdasarkan hasil belajar yang dikembangkan dalam kurikulum. Keempat, bentuk hasil. Ini membantu untuk meringkas hasil analisis konseptual dan menentukan perilaku subjek penelitian. 
Kumpulan objek itu dijadikan dasar dalam mengedit tes serta merancang perangkat pembelajaran dan diintegrasikan ke dalam.

Tahapan kedua, yaitu perancangaan yang bertujuan untuk merancang bahan ajar sesuai dengan indikator serta hasil pembelajaran yang telah ditentukan. Sebelum bahan ajar diuji terhadap murid, Bahan yang ada divalidasi terlebih dahulu guna memeriksa kelayakannya.

Tahapan ketiga, yaitu tahap pengembangan, yang bertujuan untuk menciptakan bahan ajar yang efektif dengan menguji keefektifan bahan ajar. Desain bahan yang diproduksi akan didiskusikan dengan validator mengenai keefektifannya. Validasi yang telah dilakukan oleh validator yang terdiri dari guru. Penguji yang berpengalaman didorong untuk mengkonfirmasi kelayakan bahan ajar dan kelayakan materi pembelajaran dan konsep pembelajaran yang dikembangkan dengan mengkritik dan memberikan saran kepada penulis yang terdapat kesenjangan yang ada dalam bahan ajar. Revisi akan dilakukan berdasarkan saran yang diberikan oleh validator (Adriani dan Sabekti, t.t., 77).

\section{HASIL DAN PEMBAHASAN PENELITIAN}

Ada 3 hal yang dijadikan landasan dalam mengembangkan bahan ajar tema 7 subtema 2 berbasis lokal materi, yaitu: 1) KI dan KD yang diajarkan dalam pembelajaran tema 7 subtema 1. 2) Karakteristik konsep materi lokal yang dapat diintegrasikan ke dalam pembelajaran. 3) Daya dukung sekolah terhadap pembelajaran berbasis lokal materi.

\section{KI dan KD yang diajarkan dalam pembelajaran tema 7 subtema 2}

Tema 7 Indahnya Keberagaman Negeriku subtema 2 Indahnya Keberagaman Budaya Negeriku memuat 12 Kompetensi Dasar (KD) dan 4 Kompetensi Inti (KI). Keseluruhan KD yang termuat dalam tema 7 subtema 1 bisa diintegrasikan ke dalam pembelajaran berbasis lokal materi. Adapun kriteria materi yang dijadikan dasar untuk menetapkan materi yang dapat diintegrasikan ke dalam pembelajaran berbasis lokal materi, yaitu: 1) Materi tersebut objek kajiannya dapat ditangkap oleh panca indra. 2) Materi tersebut menuntut penalaran untuk mempelajarinya. 3) Materi tersebut memungkinkan penggunaan model, metode, strategi, pendekatan serta media dan alat peraga dalam pembelajarannya. Dari ke $12 \mathrm{KD}$ yang terdapat dalam tema, keseluruhan KD tersebut dapat memenuhi kriteria untuk dimasukkan dalam bahan ajar berbasis lokal materi.

\section{Karakteristik konsep materi lokal yang dapat diintegrasikan ke dalam pembelajaran}

Konsep lokal yang dapat dalam materi sehingga diintegrasikan ke dalam pembelajaran tema 7 subtema 2 adalah konsep materi gerak tari daerah. Adapun konsep gerak tari daerah yang relevan untuk diintegrasikan ke dalam tema 7 subtema 2 meliputi, jenis tari daerah, ciri-ciri tari daerah, gerak tari daerah, unsur-unsur gerak tari daerah, perlengkapan yang digunakan pada tari daerah, musik tari daerah, alat musik yang digunakan dalam tari daerah dan memeragakan tari daerah.

Setelah dikaji dan disisipi dengan lokal materi, ditemukan bahwa seluruh Kompetensi Dasar yang terdapat di tema 7 subtema 2 memiliki kesempatan untuk memperkenalkan konsep gerak tari daerah berbasis masyarakat yang digunakan sebagai latar belakang lingkungan belajar siswa. Peluang ini disebabkan oleh kenyataan bahwa pembelajaran yang dominan tidak lagi berfokus pada konten tetapi berfokus pada kompetensi. Penjelasan Kompetensi Dasar yang terdapat dalam tema 7 subtema 2 menemukan konsep-konsep lokal materi yang dapat diintegrasikan ke dalam pembelajaran.

Selain sebagai wadah untuk mewariskan konsep-konsep lokal materi, pembelajaran berbasis lokal materi dapat dijadikan sebagai suatu alat untuk menanamkan kearifan lokal kepada siswa. Contohnya ketika guru mengatakan berbagai jenis tari daerah kepada siswa, siswa bisa diajarkan tentang pentignya melestarikan budaya asli daerah agar jenis-jenis tari yang ada tidak hilang karena adanya pengaruh globalisasi. 
3193 Pengembangan Bahan Ajar Tema 7 Indahnya Keberagaman Negeriku Subtema 2 Berbasis Lokal di Sekolah Dasar - Badratun Nafis, Maylana Nurfariha, Srimau Aisyah, Tria Marvida

DOI: https://doi.org/10.31004/edukatif.v3i5.1121

\section{Daya dukung sekolah terhadap pembelajaran berbasis lokal materi}

Dukungan sekolah terhadap pembelajaran berbasis lokal materi pada tema 7 subtema 2 dapat dilihat dalam 3 hal, yaitu: 1) manajemen sekolah, 2) sumber daya manusia (SDM), 3) dan sumber daya pendukung (SDP). Manajemen disekolah SDN 1 Peukan Bada secara umum terbuka terhadap inovasi akademik, termasuk kesediaaan menampung berbagai informasi yang didapatkan dari dokumen lokal. Sumber Daya Manusia (SDM) yang dimiliki SDN 1 Peukan Bada sangat memadai untuk mengimplementasikan materi secara lokal.

Sumber belajar utama yang digunakan oleh guru SDN 1 Peukan Bada adalah buku tematik yang diadakan oleh sekolah melalui bantuan pemerintah yang biasa disebut sebagai buku paket, dan didukung dengan buku-buku suplemen seperti Lembar Kerja Siswa (LKS). Berdasarkan hasil analisis Rencana Pelaksanaan Pembelajaran (RPP) yang dilakukan oleh guru SDN 1 Peukan Bada, selama mengajar, guru membuat rencana pembelajaran yang berpusat pada siswa dengan melakukan pembelajaran sesuai dengan karakteristik siswa dan materi pembelajaran.

Sumber Daya Pendukung (SDP) yang dikaji dalam penelitian ini meliputi keberadaan sarana dan parasarana pembelajaran disekolah. Ketersediaan sarana dan prasarana di SDN 1 Peukan Bada sudah dapat mendukung pembelajaran berbasis lokal materi. Contohnya, seluruh siswa dan guru masing-masing memiliki buku paket. Selain itu, sumber belajar utama yang digunakan adalah buku tema 7 Indahnya Keberagaman Negeriku yang diterbitkan oleh satuan penerbit.

Analisis kebutuhan kurikulum 2013, Bahan ajar adalah segala bentuk bahan yang digunakan untuk membantu guru atau instruktur dalam melaksanakan proses pembelajaran di kelas. Bahan yang dimaksud bisa berupa bahan tertulis maupun bahan tak tertulis (Sofan Amri 2010, 159). Sedangkan menurut pannen bahan ajar merupakan serangkaian materi yang dikemas secara sistematis untuk menciptakan lingkuangan atau suasana di mana siswa dapat belajar dengan nyaman. (Pannen, P \& Purwanto 2011, 20). Andi Prastowo berpendapat bahwa semua materi adalah dokumen (yang berupa informasi, alat, teks) yang dikemas secara sistematis, memberikan gambaran lengkap tentang keterampilan yang dimiliki siswa dan digunakan dalam proses pembelajaran untuk tujuan perencanaan dan pembelajaran. Contoh: buku paket pelajaran, formulir, dokumen, lembar kerja template, materi audio, materi interaktif (Andi Prastowo 2014, 43).

Nilai-nilai budaya juga dieskpresikan dalam cara hidup, yang berupa aktivitas manusia yang benarbenar mencerminkan nilai-nilai budaya yang terkandung. (Jujun S. Suriasumantri 2005, 262). Dinamika kehidupan masyarakat membentuk seperangkat nilai unik yang dianut oleh warga negara atas dasar budaya yang diciptakan oleh masyarakat setempat, dihormati banyak orang, dan dipratikkan oleh masyarakat. Dalam konteks kebangsaan, interaksi budaya lokal menciptakan nilai budaya baru dalam kehidupan berbangsa dan bernegara. (Trianto 2010, 174-175). Ada nilai-nilai dalam kehidupan sosial yang membentuk budaya yang terdapat di masyarakat Indonesia.

Kearifan lokal itu bersifat dinamis, lentur, terbuka dan senantiasa menyesuaikan dengan zamannya. Konsep demikian juga sekaligus memberikan gambaran bahwa kearifan lokal selalu terkait dengan kehidupan manusia dan lingkungannya. Kearifan lokal muncul sebagai penjaga atau filter (tameng) iklim global yang melanda kehidupan manusia. Kearifan adalah proses dan produk budaya manusia, dimanfaatkan untuk mempertahankan hidup. Contohnya setiap daerah memiliki aneka tradisi lokal yang mungkin akan tergolong kearifan lokal (Ani Kardawati 2017, 17).

Dalam budaya lokal, budaya mencakup ritual adat, warisan budaya, wisata alam, transportasi tradisional, permainan tradisional, infrasruktur budaya, pakaian tradisional, warisan budaya, museum, budaya, seni, kerajinan, cerita rakyat, mainan anak-anak, boneka. Sumber budaya lokal lainnya bisa berupa lingkaran kehidupan. Hal ini termasuk tinkenban, kelahiran, sunat, pernikahan, dan kematian. Budaya lokal dapat menjadi bahasa humor untuk pendidikan karakter. (Ma'as Shobirin 2016, 91). Adapun karakteristik dari kearifan lokal merupakan sebuah budaya kontekstual. Kearifan selalu bersumber dari hidup manusia. Ketika hidup itu berubah, kearifan lokal pun akan berubah pula (Setyosari 2015, 14). 
Pendidikan berbasis masyarakat adalah pembelajaran yang mengajarkan siswa untuk mendekati situasi khusus yang mereka hadapai sehari-hari. Model pendidikan berbasis budaya lokal merupakan contoh pendidikan yang sangat relevan dengan life development skills, berdasarkan penguatan keterampilan dan potensi lokal di masing-masing daerah. (Wagiran, t.t.) Budaya lokal Indonesia beragam, karena Indonesia terdiri dari berbagai kelompok etnis yang berbicara beberapa bahasa daerah dan mempraktikkan beberapa ritual tradisional. hadirnya pendatang luar, serta etnis Tionghoa, Arab dan India dan negeri lainnya, semakin memperkaya keragaman budaya lokal.

Pendidikan berbasis budaya lokal dapat dijadikan salah satu cara untuk menjaga potensi daerah masing-masing. Budaya lokal harus dikembangkan dari potensi daerah masing-masing. Potensi daerah adalah potensi sumber daya tertentu yang dimiliki oleh daerah tertentu. Salah satu contohnya adalah potensi tari saman yang dimiliki Aceh, tari seudati, kerajinan, makanan khas Aceh dan lain sebagainya.

Dengan mengintegrasikan kecerdasan budaya daerah ke dalam fungsi belajar anak dan konsepsi pembentukan kerpibadian, anak secara tidak langsung dihubungkan dengan identitas pribadi dan budaya baiknya yang telah lama menjadi anggota masyarakat. Anak dapat pula melihat gambaran besarnya. Selain itu, melalui pendidikan berbasis kecerdasan budaya daerah dimungkinkan untuk memperoleh pengetahuan berdasarkan kearifan budaya masyarakat setempat, memperoleh keterampilan dalam proses memahami daerah dalam proses kehidupan dan memililki sikap, perilaku selaras dengan budaya lokal tersebut. (Ani kadarwati \& ibadullah Malawi 2017, 13).

\section{KESIMPULAN}

Berdasarkan hasil penelitian dan pembahasan di atas, maka disimpulkan Tema 7 Indahnya Keberagaman Negeriku subtema 1 Keberagaman Suku Bangsa dan Agama di Negeriku memuat 12 Kompetensi Dasar (KD). Keseluruhan KD yang termuat dalam tema 7 subtema 1 bisa diintegrasikan ke dalam pembelajaran berbasis lokal materi. Konsep lokal materi yang dapat diintegrasikan ke dalam pembelajaran tema 7 subtema 2 adalah konsep materi gerak tari daerah. pembelajaran berbasis lokal materi dapat dijadikan sebagai suatu alat untuk menanamkan kearifan lokal (local wisdom) pada diri siswa. Sebagai contoh ketika menjelaskan berbagai jenis tari daerah kepada siswa, siswa bisa diajarkan tentang pentignya melestarikan budaya asli daerah agar jenis-jenis tari yang ada tidak hilang karena adanya pengaruh globalisasi.

Hasil analisis terhadap Rencana Pelaksanaan Pembelajaran (RPP) yang disusun oleh guru di SDN 1 Peukan Bada menujukkan bahwa dalam mengajar guru telah membuat perencanaan pembelajaran yang berpusat pada siswa, dengan menerapkan pembelajaran yang sesuai dengan karakteristik materi ajarnya. Ketersediaan sarana dan prasarana di SDN 1 Peukan Bada sudah dapat mendukung pembelajaran berbasis lokal materi. Contohnya, seluruh siswa dan guru masing-masing memiliki buku paket. Selanjutnya, sumber belajar utama yang dipakai adalah buku tema 7 Indahnya Keberagaman Negeriku yang diterbitkan oleh satuan penerbit.

\section{DAFTAR PUSTAKA}

Adriani, Nina, Dan Ardi Widhia Sabekti. T.T. "Tingkat Validitas Media Pembelajaran Kimia Berbasis Android Validity Of Android-Based Chemistry Learning Media," 5.

Akbar, S, Dan H Sriwijaya. 2011. Pengembangan Kurikulum Dan Pembelajaran Ilmu Pengetahuan Sosial. Cipta Media. Yogyakarta.

Andi Prastowo. 2014. Pengembangan Bahan Ajar Tematik Tinjauan Teoretis Dan Praktis. Jakarta: Kencana Prenadamedia Group. 
3195 Pengembangan Bahan Ajar Tema 7 Indahnya Keberagaman Negeriku Subtema 2 Berbasis Lokal di Sekolah Dasar - Badratun Nafis, Maylana Nurfariha, Srimau Aisyah, Tria Marvida DOI: https://doi.org/10.31004/edukatif.v3i5.1121

Ani Kadarwati \& Ibadullah Malawi. 2017. "Pembelajaran Tematik (Konsep Dan Aplikasinya).” Dalam , 13. Jawa Timur: CV.AE Media Grafika.

Ani Kardawati, Ibadullah Malawi. 2017. "Pembelajaran Tematik (Konsep Dan Aplikasinya)." CV.Ae Media Grafika, 17.

Destrinelli, Dwi Kurnia Hayati, Dan Endang Sawinty. 2018. "Pengembangan Media Konkret Pada Pembelajaran Tema Lingkungan Kelas III Sekolah Dasar.” Jurnal Gentala Pendidikan Dasar 03 (2).

Divan, Stefanus. 2018. "Pengembangan Bahan Ajar Tematik Berbasis Budaya Lokal Untuk Siswa Kelas IV Sekolah Dasar." Ilmu Pendidikan: Jurnal Kajian Teori Dan Praktik Kependidikan 3 (12).

Jujun S. Suriasumantri. 2005. Filsafat Ilmu. XVI. Jakarta: Pustaka Sinar Harapan.

Latifah, Niniek. 2018. "Pengembangan Bahan Ajar Berbasis Budaya Lokal Subtema Indahnya Keragaman Budaya Negeriku Di Kelas IV Sekolah Dasar.” Skripsi, Jambi: Universitas Jambi.

Ma'as Shobirin. 2016. “Konsep Dan Implementasi Kurikulum 2013 Di SD/MI.” Dalam , 91. Yogyakarta: CV. Budi Utama.

Nana Syaodih Sukmadinata, Alexon \&. 2010. "Pengembangan Model Pembelajaran Terpadu Berbasis Budaya Untuk Meningkatkan Apresiasi Siswa Terhadap Budaya Lokal.” Jurnal Cakrawala Pendidikan 2 (2).

Pannen, P \& Purwanto. 2011. "Penulisan Bahan Ajar." Dalam Pusat Antar Universitas, 20.

Rusman. 2010. Model-Model Pembelajaran. PT Raja Grafindo Persada. Bandung.

Setyosari, Punaji. 2015. "Metode Penelitian Pendidikan Dan Pengembangan.” Prenada Media, 14.

Sofan Amri, Iif Khoiru Ahmadi. 2010. "Konstruksi Pengembangan Pembelajaran Pengaruhnya Terhadap Mekanisme Dan Praktik Kurikulum." PT Prestasi Pustakaraya, 159.

Suja, I Wayan. 2011. "Analisis Kebutuhan Pengembangan Buku Ajar Sains SD Bermuatan Pedagogi Budaya Bali." Jurnal Pendidikan Dan Pengajaran 44 (1-3).

Trianto. 2010. Model Pembelajaran Terpadu. Jakarta: Bumi Aksara.

Wagiran. T.T. "Pengembangan Model Pendidikan Kearifan Lokal Dalam Mendukung Visi Pembangunan Provinsi Daerah Istimewa Yogyakarta 2020 (Tahun Kedua)" 3 (3).

Warpala, IWS, IW Subagia, Dan IW Suastra. 2010. "Pengembangan Bahan Ajar Berbasis Kearifan Lokal Untuk Mata Pelajaran Sains SMP.” Jurnal Penelitian Dan Pengembangan Pendidikan.

Wijiningsih, Ninik, Wahjoedi, Dan Sumarmi. 2017. "Pengembangan Bahan Ajar Tematik Berbasis Budaya Lokal." Jurnal Pendidikan: Teori, Penelitian Dan Pengembangan 2 (8). 